\title{
DAMPAK PERNIKAHAN USIA DINI TERHADAP KESEHATAN REPRODUKSI
}

\author{
${ }^{1}$ Shafa Yuandina Sekarayu, ${ }^{2}$ Nunung Nurwati \\ 1shafa19014@mail.unpad.ac.id, ${ }^{2}$ nngnurwati@yahoo.co.id \\ 1,2 Ilmu Kesejahteraan Sosial, Fakultas Ilmu Sosial dan Ilmu Politik UniversitasPadjadjaran
}

\begin{abstract}
ABSTRAK
Pernikahan merupakan ikatan lahir dan batin berupa penyatuan antara laki-laki dan perempuan atas dasar keinginan untuk memiliki keturunan dan keluarga. Pada dasarnya pernikahan dilakukan oleh seseorang yang telah memiliki kematangan dalam segi fisik, psikologis, dan ekonomi. Namun, di Indonesia sekitar 12 - 20\% masih bisa ditemukan pernikahan yang belumdisertai dengan kesiapan dari berbagai aspek seperti fisik, ekonomi, dan pengetahuan mengenaikehidupan rumah tangga. Artikel ini menggunakan metode penelitian kualitatif dan deskriptifyang akan menggali lebih dalam mengenai pernikahan dini dan keterkaitannya dengan kesehatan reproduksi. Pernikahan usia dini dilakukan oleh seseorang yang rata-rata berusia dibawah 19 tahun yang rata-rata belum siap dalam berbagai aspek dalam pernikahan. Hal ini kemungkinan akan berdampak terhadap kesehatan reproduksi baik untuk perempuan maupun laki-laki. Oleh karena itu, diperlukan persiapan yang dari berbagai aspek dalam melaksanakan pernikahan sehingga upaya untuk menghindari dampak buruk pernikahan usia dini terhadap kesehatan reproduksi dapat diminimalisir.
\end{abstract}

Kata kunci: Pernikahan dini, Dampak, Kesehatan Reproduksi

\begin{abstract}
Marriage is a physical and spiritual bond in the form of a union between a man and a womanbased on the desire to have offspring and a family. Basically, marriage is carried out by someone who has matured physically, psychologically and economically. However, in Indonesia, around $12-20 \%$ can still be found marriages that have not been accompanied by readiness from various aspects such as physical, economic, and knowledge of household life. This article uses qualitative and descriptive research methods that will explore more about early marriage and its relation to reproductive health. Early marriage is carried out by someone who is under 19 years old on average who is not ready for various aspects of marriage. This is likely to have an impact on reproductive health for both women and men. Therefore, various aspects of preparation are needed in carrying out the marriage so that efforts to avoid the negative impact of early marriage on reproductive health can be minimized.
\end{abstract}

Key words: Early marriage, Impact, Reproduction Health 
Jurnal Pengabdian dan

Penelitian Kepada Masyarakat

(JPPM)

\section{PENDAHULUAN}

Pernikahan ialah momentum yang sangat berarti untuk setiap hidup manusia yang berupa jalinan lahir batin antara seseorang laki-laki dan perempuan sebagai suami dan istri dengan tujuan membentuk keluarga yang harmonis dan kekal berdasarkan Ketuhanan Yang Maha Esa. Selain mempersatukan dua orang yang berbeda, pernikahan akan secara otomatis mengubah status keduanya. Undangundang mengenai perkawinan tertera dalam Undang-Undang No. 1 tahun 1974, pasal 7ayat (1) menyatakan bahwa pekawinan dizinkan apabila pihak pria sudah mencapai umur 19 tahun dan pihak wanita telah mencapai umur 16 tahun. Namun dilakukan perubahan dan revisi kembali menjadi perkawinan bisa dilakukan apabila pihak dari laki-laki dan pihak perempuan berusia minimal 19 tahun, kemudian dilanjut ayat 2 yang menyatakan bahwa pernikahan masing-masing calon yang belum mencapai usia 21 tahun, harus mendapatkan izin dari kedua orang tua. Kemudian, pihak Badan Kependudukan dan Keluarga Berencana Nasional (BKKBN) juga telah mengeluarkan aturan bahwa usia ideal menikah pihak perempuan adalah 20-35 tahun dan 25-40 tahun untuk pihak pria (BKKBN, 2020).

Analisis Survei Penduduk Antar Sensus (SUPAS) menyatakan sebanyak 3.000 perempuan pada usia 20-24 tahuh melakukan pernikahan pertama melakukan pernikahan pertama sebelum berusia 15 tahun. Di sisi lain, pada 1 dari 100 laki-laki melakukan pernikahan pertama pada usia 2024 tahun yang terjadi di pedesaan maupun di kota. Pernikahan dini bisa dikatakan sebagai pernikahan yang dilakukan oleh anak. Dalam Undang- Undang Nomor 4 Tahun 1979 tentang kesejahteraan anak, penafsiran anak merupakan seseorang yang wajib mendapatkan hak-hak yang kemudian hak-hak tersebut bisa memjamin perkembangan serta pertumbuhan dengan baik secara rahasia, jasmaniah, maupun sosial (Sangaji, 2017). Anak juga memiliki hak untuk memperoleh pelayanan untukmengembangkan kemampuan dan kehidupan sosialnya, dan memperoleh perlindungan baik dalam kandungan maupun sesudah dilahirkan.

Pernikahan bukan hanya persoalan suatu perubahan status dan pengesahan kehidupan bersama antara seorang laki-laki dan perempuan namun lebih dari itu, pernikahan merupakan hubungan serta kegiatan yang sakral berbentuk penyatuan dua insan yang akan mengemban tanggung jawab yang tidak mudah, sehingga diperlukan kedewasaan dari aspek usia, kesehatan jasmani, psikologis, biologis, dan ekonomi dari kedua pasangan untuk menjalaninya. Namun realitasnya masih ada ketidaksesuaian dengan yang dicantumkan dalam aturan dan Undang- Undang. Pada faktanya masih banyak terdapat warga di Indonesia yang masih melakukan pernikahan dibawah umur dari ketentuan yang sudah dikeluarkan oleh Badan Koordinasi Keluarga Berencana Nasional (BKKBN), terutama warga yang terletak di pedesaan. Bersumber pada informasi Child Marriage Report, biladiamati dari wilayah tempat tinggalmembuktikan jika kebiasaan pernikahan anak perempuan kemungkinan lebih besar terjadi di perdesaan dibanding perkotaan, baik itu saat berusisa sebelum 18 tahunataupun saat sebelum umur 15 tahun. Pada tahun 2018, perempuan berusia 20-24 tahun di perdesaan akan melaksanakan pernikahan pertamanya sebelum berusia 18 tahun, persentase lebih besar ditunjukkan terdapat di perdesaan ialah sebesar $16,87 \%$ sedangkan perkotaan sebesar $7,15 \%$. Sebaliknya untuk anak laki-laki, kurang lebih 1 dari 100 laki- laki berusia 20-24 tahun pada tahun 2018 sudah melakukan pernikahan sebelum umur 18 tahun. Sama hal nya dengan anak perempuan yang telah melakukan pernikahan dini, di daerah pedesaan juga mempunyai jumlah yang tinggi untuk anak laki-laki yang melakukan pernikahan dini yakni sebesar 1,44\% serta perkotaan yaitu 0,77\% (Sahrizal, Handayani, P. S., \& dkk, 2020).

Badan Koordinasi Keluarga Berencana Nasional (BKKBN) dan UndangUndang yang mengatur batasan usia dalam menikah tentunya dilandaskan berbagai hal. Pelaksanaan pernikahan sebelum usia yang ditentukan memiliki resiko yang bisa dirasakan oleh pihak perempuan maupun laki-laki. Ketidaksiapan anak pada usia yang belum siap menikah dapat menyebabkan berbagai hal, misalnya putusnya pendidikan, menganggu kesehatan reproduksi, perceraian 
pada usia muda, kekerasan dalam rumah tangga, dan lain sebagainya. Selain itu, pernikahan dini juga menimbulkan dampak buruk secara mental atapun fisik. Terdapat beberapa aspek yang menjadi pemicu atau faktor terjadinya pernikahan dini, antara lain kebutuhan ekonomi, pendidikan rendah, kultur nikah muda, perkawinan yang diatur, dan seks bebas pada remaja yang menyebabkan kehamilan sebelum menikah (Himsya, 2011). Faktor ekonomi dan kemiskinan menyebabkan orang tua tidak sanggup memenuhi kebutuhan anaknya dan tidak mampu membiayai sekolah alhasil mereka memutuskan untuk menikahkan anaknya dengan harapan sudah lepas tanggung jawab untuk membiayai kehidupan anaknya ataupun dengan harapan anaknya bisa memperoleh kehidupan yang lebih baik. Faktor orang tua menyetujui perkawinan di usia muda ini juga seringkali dikarenakan oleh kekhawatiran orang tua akan terjadinya hamil diluar nikah sehingga mendorong anaknya untuk menikah diusia yang masih belia (F Jannah., 2012). Secara umum, pernikahan dini lebih kerap terjadi didalam kalangan keluarga kurang mampu, walaupun tidak membantah bisa terjadi pula di kalangan keluarga ekonomi atas.

Selain itu, Badan Koordinasi Keluarga

Berencana Nasional (BKKBN) juga memberikan arahan perihal umur minimum seseorang untuk melakukan pernikahan. Hal ini disebabkan memperhitungkan dari berbagai aspek seperti, kesiapan reproduksi, biologis, dan psikis (BKKBN, 2017). Serupa adanya kemungkinan perceraian, kesehatan ibu dananak saat melahirkan, meningkatnya angka fertilitas serta banyak hal lainnya. Pada kesehatan mental yaitu saat memasuki dunia rumah tangga yang mana terdapat hak serta kewajiban yang perlu dipenuhi sebaik mungkin, sehingga keharmonisan dalam rumah tangga dapat terwujud. Dalam konteks ini, dibutuhkan kesehatan mental dan tidak hanya bermodal cinta. Tidak sedikit pernikahan yang dilakukan karena keterpaksaan, yang mana hal ini akan mempengaruhi keharmonisan rumah tangga dikarenakan suami dan istri belum memiliki mental yang siap untuk menikah di usia muda dan resiko terjadi perceraian akan semakin besar(Fitriyani, D., \& dkk). Secara fisik, remaja perempuan belum memiliki tulang panggul yang masih terlalukecil sehingga bisa membahayakan proses persalinan. Apabila dianalisis dampak negatif perkawinan dini lebih banyak dari pada dampak positifnya (Hanum \& Tukiman, 2015).

\section{METODE}

Metode yang digunakan dalam penelitian ini dilakukan melalui penelitian deskriptif dan penelitian kualitatif. Metode penelitian deskriptif menurut Nazir (1988) dalam Buku Contoh Metode Penelitian, adalah suatu metode yang digunakan dalam meneliti kondisi, sistem pemikiran, atau peristiwa pada masa sekarang. Penelitian deskriptif ini, bertujuan untuk mendeskripsikan atau membuat gambaran secara sistematis dan akurat mengenai fakta yang ada. Dalam penelitian ini penulis mengenakan pendekatan kualitatif sebagai metode penelitian yang menghasilkan informasi deskriptif berbentuk kata-kata yang tertulis atau lisan dari orang-orang danperilaku yang diamati (Bogdan, R., \& Taylor, 1993). Pada penelitian ini akan berfokus kepada pemahaman terhadap fenomena secara mendalam melalui pengumpulan data yang dapat menunjukkan detail dan pemahaman suatu data yang diteliti. Oleh karena itu, kedua pendekatan ini digunakan untuk mendeskripsikan serta menggambarkan fenomena pernikahan dini dan faktor-faktor yang berkaitan dengan masalah kesehatan reproduksi akibat pernikahan dini.

\section{HASIL \& PEMBAHASAN}

\section{Pernikahan Dini}

Pernikahan dini dapat didefinisikan sebagai ikatan lahir dan batin antara seorang pria dengan wanita sebagai suami dan istri pada usia yang masih muda atau remaja. Dalam pasal 1 Undang-Undang No 1 Tahun 1974 tentang pernikahan, mendefinisikan bahwa pernikahan ialah ikatan lahir batin antara seorang pria dengan seorang wanita sebagai suami istri dengan tujuan membentuk keluarga (rumah tangga) yang bahagia dan 
Jurnal Pengabdian dan

Penelitian Kepada Masyarakat

(JPPM)

e ISSN: 2775 - 1929

p ISSN: $2775-1910$

Vol. 2 No.1

Hal: 37 - 45

April 2021

kekal berdasarkan Ketuhanan Yang Maha Esa (Kartono, 1922). Dalam Undang-UndangNo. 1 tahun 1974, pasal 7 ayat (1) juga menyatakan bahwa perkawinan hanya disahkan jika pihak pria sudah mencapai umur 19 dan pihak wanita sudah mencapaiumur 16 tahun, usulan perubahan pada pasal 7 tahun 1974 ayat (1) perkawinandapat dan dilakukan jika pihak lakilaki danperempuan berusia minimal 19 tahun, ayat untuk melangsungkan perkawinan masing-masing calon mempelai yang belum mencapai umur 21 tahun, harus mendapat izin kedua orangtua, sesuai dengan kesepakatan pihak Badan Kependudukan dan Keluarga Berencana Nasional (BKKBN) yang telah melakukan kerjasama dengan MOU yang menyatakan bahwa Usia Perkawinan Pertama diizinkanapabila pihak pria mencapai umur 25 tahun dan wanita mencapai umur 20 tahun (Rokhim \& Sirait, 2016).

Maka akan diperoleh kesimpulan bahwa seseorang yang menikah sebelumumur yang ditentukan berdasarkan undang-undang adalah termasuk pernikahan dini. Pernikahan dini atau kawin muda sendiri adalah pernikahan yang dilakukan oleh pasangan atau salah satu padangan yang masih dikategorikan remaja yang berusia dibawah 19 tahun. Menurut Dlori (2005) Pernikahan dini adalah sebuah pernikahan dibawah umur yang dapat dikatakan memiliki persiapan yang bisa dikatakan belum maksimal secara fisik, psikologis, maupun ekonomi. Pernikahan usia muda adalah perkawinan yang dilakukan di bawah usia 20 tahun (BKKBN, 2010). Bila merujuk pada bidang kesehatan, menujukkan bahwa pernikahan atau perkawinan yang ideal adalah perempuan yang sudah berusia diatas 20 tahun, hal ini berdasarkan pertimbangan kesehatan reproduksinya. Pernikahan yang dilakukan dibawah umur 20 tahun dapat menimbulkan risiko terkena kanker leher rahim, sel-sel rahim yang belum siap, dan kemungkinan terkena penyakit Human Papiloma Virus (HIV).

\section{Faktor-Faktor yang Mempengaruhi Pernikahan Dini}

a. Faktor Pendidikan

Tingkatan pendidikan yang rendah atau tidak melanjutkan pendidikan ke jenjang yang lebih lanjut dalam hal ini dapat mendorong seseorang untuk melakukan pernikahan dini. Selain itu tingkat pendidikan keluarga juga dapat memengaruhi terjadinya pernikahan usia muda. Pernikahan usia muda juga dipengaruhi oleh tingkat pendidikan masyarakat, secara keseluruhan. Beberapa masyarakat yang tingkat pendidikannya rendah akan cenderung untuk menikahkan anaknya dalam usia masih muda. Bersumber pada penelitian yang dilakukan Kecamatan Gejugjati dan Lekok Kabupaten Pasuruan sebanyak $35 \%$ pasangan yang menikah di bawah umur dipengaruhi oleh faktor pendidikan (Saipul ,2011 dalam Hanggara, 2006). Hal ini dapat disimpulkan bahwa pendidikan merupakan salah satu faktor yang menjadi penyebab dalam pernikahan dini yaitu pendidikan remaja maupun pendidikan orang tua. Dalam faktor pendidikan akan sangat berpengaruh terhadap faktor ekonomi.

b. Faktor Ekonomi

Berdasarkan penelitian yang dilakukan oleh UNICEF \& UNFPA (2018) menyatakan bahwa kemiskinan menjadi salah satu faktor yang memiliki pengaruh besar dalam mendorong terjadinya pernikahan dini dikarenakan beberapa wilayah, seperti di Indonesia, perempuan masih sering di berikan label sebagai beban ekonomi keluarga. Orang tua yang menjadikan alasan kesejahteraan ekonomi untuk melakakukan pernikahan dini terhadap anaknya, memiliki anggapan bahwa dengan merelakan anak perempuannya untuk dinikahkan dapat meringankan kebutuhan hidup untuk orang tuanua. Kemudian, pengeluaran dalam rumah tangga dan pendapatan juga menjadi salah satu indikator bagaimana tingkat kesejahteraan hidup bagi sebuah keluarga (Astuty, n.d.).

c. Faktor Budaya

Pernikahan dini terjadi karena orang tua dari anak memiliki kekhawatiran anaknya tidak kunjung menikah dan menjadi perawan tua. Faktor adat dan budaya, di beberapa daerah di 
Indonesia, masih memiliki beberapa pemahaman yang berbeda-beda tentang perjodohan. Pemahaman ini berupa saat anak perempuan telah mengalami menstruasi maka, akan harus segera dijodohkan. Padahal umumnya umumnya anak-anak perempuan mulai menstruasi di usia 12 tahun. Sehingga, dapat dipastikan anak tersebut akan dinikahkan pada usia 12 tahun, jauh di bawah usia minimum sebuah pernikahan yang diamanatkan Undang-Undang (Ahmad, 2009). Hal ini diperkuat oleh penelitian yang dilakukan Hanggara di Kecamatan Gegugjati Kabupaten Pasuruan tahun 2010 yaitu $61,6 \%$ remaja yang melakukan perkawinanusia dini karena faktor budaya. Dimana faktor budaya di sini adalah orang tua yang menjodohkan atau memaksa kawin anaknya.

d. Faktor MBA (Marriaged By Accident) Di Indonesia kasus pernikahan dinisering kali disebabkan karena hamil sebelum menikah atau Marriaged By Accident (MBA). Menurut Sarwono (2003) pernikahan usia dini sering sekali terjadi pada anak-anak yang sedang mengalami masa pubertas, hal ini disebabkan remaja sangat rentan kaitannya untuk melakukan perilaku seksual yang mereka lakukan sebelum menikah. Maka dapat dismpulkan bahwa pergaulan bebas dapat menjadi salah satu faktornya. Akibat terlalu bebasnya pergaulan remaja, terutama dalam hubungan berpacaran, remaja bisa sampai melakukan seks pranikah dan kehamilan diluar pernikahan.

\section{Kesehatan Reproduksi}

Masa remaja merupakan masa peralihan dari masa kanak-kanak menuju dewasa dengan berbagai perubahan baik secara fisik, emosi, sosial, dan nilai-nilai moral. Oleh karena itu, masa remaja relatif bergejolak dibandingkan dengan masa perkembangan lainnya. Pada tahap remaja tengah menjadi sangat penting, dikarenakan pada masa ini remaja berada pada tahap masa pencarian identitas diri, membutuhkan peran teman sebaya, menghadapi kondisi kebingungan karena belum mampu menentukan aktivitas yang bermanfaat dan memiliki keingintahuan yang tinggi terhadap berbagai hal yang belum diketahui (Marino, \& Spada, 2020). Pubertas yang dahulu dinilai sebagai sebuah acuan kedewasaan seseorang, ternyata kini sudah tidak valid lagi, hal ini disebakan usia remaja mengalami pubertas terjadi pada akhir belasan yaitu 15-18 tahun kini berubaha menjadi awal belasan adapun anak yang mengalami pubertas sebelum usia 11 tahun.

Kesehatan reproduksi menjadi perhatian khusus secara di seluruh dunia sejak diangkatnya isu tersebut dalam Konferensi Internasional mengenai Kependudukan dan Pembanginan (International Conference on Populationand Development, ICPD), di Kairo Mesir pada tahun 1994. Demikian pula dengan konvensi tentang perempuan, juga belum memberi penekanan pada Hak Asasi Manusia atau isu yang mempedulikan reproduksi dan seksualitas (Okara, 2005). Dalam hal ini telah disepakati pentingnya perubahan pandangan dalam pengelolaanmasalah kependudukan dan pembangunan dari pendekatan pengendalian populasi dan penurunan fertilitas menjadi pendektana yang memiliki fokus mengenai kesehatan reproduksi. Pandangan baru ini memiliki pengaruh yang besar terhadap hak dan peran perempuan sebagai subyek dalam Keluarga Berencana. Perubahan pendekatan juga terjadi dalam penanganan kesehatan ibu dan anak, kesehatan reproduksi remaja, pencegahan dan penanggulangan Infeksi Menular Seksual (IMS) termasuk HIV/AIDS, serta kesehatan reproduksi usia lanjut, yang dibahas dalam konteks kesehatan dan hak reproduksi. Dengan paradigma baru ini diharapkan kestabilan pertumbuhan penduduk akan dapat dicapai dengan lebih baik.

Proses reproduksi terjadi melalui hubungan seksual antara laki-laki dan perempuan, kesehata reproduksi meliputi kesehatan seksual yang menuju pada peningkatan kualitas hidup dan relasi antar individu. Dalam konteks pengembangan manusia, pelayanan kesehatan reproduksi merupakan hal yang penting, hal ini dikarenakan berdampak pada kualitas hidup seseorang pada generasi berikutnya. Seseorang bisa menjalankan peranan serta proses reproduksi secara aman dan sehat bisa terlihat 
Jurnal Pengabdian dan

Penelitian Kepada Masyarakat

(JPPM)

dari bagaimana kondisi kesehatan selama siklus hidupnya, mulai dari kanak-kanak, remaja, dewasa, hingga masa pasca usia reproduksi (Sarwono,2001). Apabila dikaitkan antara masa remaja dan kesehatan reproduksi, masa remaja merupakan proses awal terbentuknya organ reproduksi. Menurut Robert Havinghurst dalam Sarlito, seorang remaja dalam menghadapi tugas-tugas perkembangan yang berkaitan dengan perubahan perubahan fisik dan peran sosial yang sedang terjadi pada dirinya. Tugas- tugas itu adalah menerima kondisi fisiknya yang berubah.

Pada saat remaja mengalami masa pubertas hormon-hormon akan mulai berfungsi, hal ini akan menyebabkan perubahan fisik dan juga mempengaruhi dorongan seks pada seorang remaja, akibat dari siapnya reproduksi dan juga dorongan dari aspek psikologis remaja akan mulai menyukai lawan jenis. Kemudian, akibatdari matangnya proses reproduksi menjadikan remaja dapat menjalankan peranan prokreasinya yang diartikan mulai bisa memiliki keturunan. Usia reproduksi yang sehat bagi perempuan adalah diantara $20-30$ tahun. Namun, masalah yang kerap muncul pada remaja adalah saat masa awal organ reproduksi telah siap, yaitu perilaku seks bebas (free sex) yang menjadi penyebab dari masalah kehamilan sebelum menikah dan resiko terkena penyakit menular seksual termasuk HIV/AIDS. Oleh karena itu kesehatan reproduksi penting untuk dipelajari karena memaparkan mengenai alat reproduksi dan fungsi serta kegunaannya.

\section{Dampak Pernikahan Dini Terhadap Kesehatan Reproduksi}

Pernikahan merupakan suatu hubungan yang bersifat sakral pada dua insan antara laki-laki dan perempuan untuk membangun sebuah rumah tangga dan memperbanyak keturunan (Ma'mun, 2015). Apabila pernikahan dini dilakukan bukan hanya karena keinginan kedua belah pihak semata, melainkan terdapat beberapa faktor pendorong lainnya, yaitu rendahnya tingkat pendidikan, kebutuhan ekonomi, budaya nikah muda, pernikahan yang diatur, seks bebas pada remaja yang menyebabkan kehamilan sebelum menikah.Pada faktor pendidikan yang cenderung rendah dan pendapatan ekonomi keluarga menjadikan anak terpaksa putus sekolah dan tidak melanjutkan pendidikan kejenjang selanjutnya. Dalam faktor pendidikan akan sangat berpengaruh terhadap faktor ekonomi. Kemiskinan menjadi salah satu faktor yang memiliki pengaruh besar dalam mendorong terjadinya pernikahan dini dikarenakan beberapa wilayah di Indonesia, perempuan masih sering di berikan label sebagai beban ekonomi keluarga. Oleh karena itu, pernikahan di usia muda dianggap menjadi jalan keluar dan tercepat untuk keluarga mengurangi beban ekonominya. Faktor lain yang mempengaruhi pernikahan dini juga erat dengan faktor kultur nikah muda. Di daerah terpencil dan pedesaan masih banyak anggapan mengenai anggapan bahwa seorang wanita hanya akan berakhir menjadi pengurus rumah, sehingga masyarakat daerah terpencil beranggapanbahwa perempuan akan lebih baik dinikahkan ketika telah melalui masa balighnya. Dari faktor-faktor yang telah diuraikan dapat disimpulkan bahwapernikahan usia dini karena faktor budaya yang sudah turun temurun.

Menurut (Badan Pusat Statistik, 2020) pada 20 provinsi pernikahan dini pada anak masih ada di atas rata-rata nasional. Provinsi dengan jumlah pernikahan dini tertinggi adalah Sulawesi Barat, Sulawesi Tengah dan Sulawesi Tenggara. Terdapat lebih dari 1 juta anak perempuan yang menikah pada usia dini. Menurut data tersebut menunjukkan kejadian pernikahan usia dini, di Jawa Barat, Jawa Timur dan Jawa Tengah menjadi 3 Provinsi sudah mencapai angka tertinggi. Seperti yang telah diuraikan sebelumnya pernikahan usia dini sangat berpengaruh terhadap kesehatan reproduksi. Pernikahan yang dilakukan oleh para remaja juga bisa memiliki pengaruh yang tidak baik terhadap berbagaihal bagi seseorang yang menjalaninya. Belum matangnya organ reproduksi dan juga kematangan fisik dari seorang remaja perempuan juga akan berpengaruh terhadap resiko jika seorang remaja perempuantersebut mengandung anaknya. Kemungkinan kecacatan pada anak, ibu mati saat melahirkan dan resiko lainnya juga sangat besar ketika perkawinan usia dini terjadi. Selain itu, leher rahim seorang remaja perempuan juga masih sensitif. Olehkarena itu, 
Jurnal Pengabdian dan

Penelitian Kepada Masyarakat

(JPPM)

jika dipaksakan untuk hamil, berisiko mengalami kanker leher rahim di kemudian hari, bahkan lebih parahnya ialah peluang resiko kematian saat melahirkan juga menjadi besar pada usia muda. Hal lain yang dapat terjadi ketika remaja perempuan hamil, adalah remaja perempuan akan lebih mudah tersebut menderita anemia selama masa kehamildan dan saat melahirkan. Minimnya pengetahuan mengenai resiko yang ada dan bisa terjadi saat seorang anak dengan usia yang belum siap ketika melakukan hubungan badan, mengandung dan juga melahirkan yang menjadi salahsatu faktor pula tingginya angka pernikahanusia dini.

Pernikahan yang dilakukan pada usia yang lebih muda akan memperpanjang masa reproduksinya. Di sisi lain untuk orang yang umur pernikahannya lebih tua akan memiliki kesempatan reproduksi yang relatif pendek. Dengan melangsungkan pernikahan di usia dini ini, akan membuka peluang lebih panjang seorang wanita mempunyai masa reproduksi. Masa reproduksi wanita yang sedang subur- suburnya ialah saat pertama mendapatkan masa menstruasi sampai berakhirnya menstruasi tersebut (menopause). Hal tersebut kurang lebih berlangsung selama

35 tahun lamanya. Ketika pernikahan pertama terjadi pada usia awal seorang wanita haid atau organ reproduksinya dapat berfungsi adalah saat tahun-tahun pertama dari 35 tahun masa reproduksinya, kemungkinan wanita tersebut melahirkan selama rentang waktu 35 tahun sangat besar (Malinda, 2012). Dampak dari kesehatan reproduksi ini bukan hanya sekedar membahas mengenai kesehatan alat-alat reproduksi tetapi juga mengenai kualitas hidup dan bagaimana kelangsungan hidup seseorang setelahnya. Pernikahan usia dini bisa menjadi perhatian seluruh dunia karenaadanya dampak buruk dari pernikahan dini yang cenderung diabaikan di beberapa Negara berkembang.

Ketika jutaan anak yang melakukan pernikahan usia dini, mereka secara otomatis baru melewati masa pubertas mereka. Apabila ditinjau dari sisikesehatan, pernikahan remaja pada usia muda dapat menimbulkan resiko kematian jika fisik remaja yang belum siap untuk hamil dan melahirkan (UNICEF, 2005). Sehingga pernikahan anak tetap merupakan pelanggaran yang mengabaikan hak-hak kesehatan dan perkembangan anak perempuan dan wanita muda Jika dikaitka dengan kesehatan reproduksi yang diakibatkan oleh pernikahan dini akan berdampak pada hubungan seksual antara laki-laki dan perempuan yang dilakukan sebelum usia matangnya pihak perempuan maupun lakilaki, dalam konteks ini definisi kesehatan reproduksi akan banyak mencakup kesehatan seksual yang mengacu pada peningkatan kualitas hidup dan hubungan antar individu. Dengan demikian bisa dilihat cara bagaimana seseorang memiliki pengetahuan mengenai pentingnya kesehatan reproduksi, bagaimana kondisi kesehatan selama siklus kehidupannya mulai dari saat konsepsi, masa remaja dan beranjak dewasa hingga masa paska usia reproduksinya dapat telihatbahwa sejauh mana seseorang dapat menjalankan fungsi dan proses reproduksinya secara aman dan sehat. Hal tersebut juga dapat berpengaruh terhadap bagaimana kehidupan yang akan dijalaninya.

Dengan menjaga kesehatan reproduksi dan mengetahui hal-hal penting yang berada didalam tubuh diri sendiri, seseorang akan lebih memikirkan dampaknya ketika ingin melakukan sesuatu. Pernikahan usia dini yang dilangsungkan oleh laki-laki dan juga perempuan akan berpengaruh terhadap usia pertama seorang perempuan menentukan panjangnya masa reproduksi. Maka, umur pernikahan pertama ini merupakan salah satu faktor yang mempunyai keterhubungan secara langsung dengantingkat fertilitas.

\section{SIMPULAN}

Pernikahan usia dini masih menjadi sebuahisu yang memiliki pusat perhatian tersendiri di masing-masing negara, terutama Indonesia di daerah-daerah terpecil. Hal ini dikarenakan beragai faktor yang dapat mempengaruhi terjadinya sebuah pernikahan dini. Perihal itu disebabkan adat istiadat serta keyakinan yang sudah turun temurun di lingkungan setempat dan hal tersebut berbaur pada remaja. Tidak hanya itu pula pernikahan usia dini bisa disebabkan karena minimnya bimbingan dalam hal kesehatan reproduksi serta seluruh akibat lain kala melaksanakan pernikahan di usia dini. Pernikahan di usia dini pula amat 
Jurnal Pengabdian dan

Penelitian Kepada Masyarakat

(JPPM)

e ISSN: $2775-1929$

p ISSN: 2775 - 1910

Vol. 2 No.1

Hal: 37 - 45

April 2021

mempengaruhi kepada banyak perihal mulai dari kesehatan ibu serta anak yang rawan tersendat, kematian ibu atau anak, terbentuknya penyakit seks yang beresiko. Hingga itu butuh untuk kitauntuk memahami secara keseluruhan dengan lebih memami apa itu pernikahan umur dini serta sebagian perihal akibat terhadap kesehatan reproduksi. Oleh karenanya diperlukan sekali bimbingan yang besar sejak mulai usia dini kepada para anak muda mengenai hal kesehatan reproduksi. Pernikahan dengan usia yang belum tepat pada waktunya akan banyak menimbulkan masalah, baik masalah fisik atau pun masalah secra psikologis. Dengan demikian membagikan penjelasan megenaihal apa yang bisa dilakukan serta perihal yang tidak bisa dilakukan yang berkaitan dengan alat reproduksinya, menghindari penyakit yang menular serta mengenali apa saja alat organ tubuh manusia bersama kegunaannya. Sebab tidak hanya manfaat mengedukasi, kesehatan reproduksi, pulabisa jadi salah satu metode melindungi dalam upaya untuk menghindari dampak buruk pernikahan usia dini. Pernikahan dinipula hendak menimbulkan ekskalasi jumlah kelahiran ataupun fertilitas penduduk di Indonesia. Oleh karena itu, pemerintah wajib lebih menerangkan peraturan hal pernikahan usia dini serta menetapkan sanksi- sanksi yang wajib diperoleh oleh masyarakat yang melaksanakannya.

\section{DAFTAR PUSTAKA}

Astuty, S. Y. (n. d. . (n.d.). FAKTORFAKTOR PENYEBAB TERJADINYA PERKAWINAN USIA MUDA. 2-3.

Badan Pusat Statistik. (2020). Pencegahan Perkawinan Anak; Percepatan yang Tidak Bisa Ditunda. $\mathrm{x}$-xii.

BKKBN. (2017). USIA PERNIKAHAN IDEAL 21-25 TAHUN. Retrieved from https://www.bkkbn.go.id/detailpost/b kkbn-usia-pernikahan-ideal-21-25 tahun

Bogdan, R., \& Taylor, S. (1993). Kualitatif (Dasar-dasar Penelitian) (terjemahan). Surabaya: Usaha Nasional.

F., J. (2012). Pernikahan Dini dan
Implikasinya terhadap Kehidupan Keluarga pada Masyarakat Madura (perspektif hukum dan gender). Egalita, 7(1).

Fitriyani, D., Nugraha, G. I., Husin, F., Mose, J. C., Sunjaya, D. K., \& Sukandar, H. (n.d.). Kajian Kualitatif Faktor-Faktor yang Memengaruhi Pernikahan Remaja Perempuan. IJEMC, 41-43.

Hanum, Y., \& Tukiman. (2015). Dampak Pernikahan Dini Terhadap Kesehatan Alat Reproduksi Wanita. Jurnal Keluarga Sehat Sejahtera, 13(26), 36-43.

Kartono, K. (1922). Psikologi Wanita Jilid2: Mengenal Wanita sebagai Ibu dan Nenek. Bandung: Mandar Maju.

Ma'mun, M. S. (2015). FAKTOR PENDORONG PERNIKAHAN DINI DI KABUPATEN BANYUWANGI.

Retrieved from http://repository.unej.ac.id/handle/12 3456789/65989

Malinda, Y. (2012). HUBUNGAN UMUR KAWIN PERTAMA DAN PENGGUNAAN KONTRASEPSI. Jurnal Kesehatan Reproduksi, 3(9).

Marino, C., Gini, G., Angelini, F., Vieno, A., \& Spada, M. M. (2020). Social norms and e-motions in problematic social media use among adolescents. Addictive Behaviors Reports, 11(November 2019), 100250. https://doi.org/10.1016/j.abrep.2020. 100250

Okara, M. (2005). Mengurangi Persoalan Kehidupan Seksual dan Reproduksi Perempuan. Yayasan Jurnal Perempuan, (41), 9.

Rokhim, A., \& Sirait, L. (2016). Tinjauan Yuridis Perkawinan Di Bawah Umur Dan Perceraian Di Pengadilan Agama Kelas Ia Samarinda.

Sahrizal, N., Handayani, P. S., Chamami, A., \& dkk. (2020). Pencegahan Perkawinan Anak: Percepatan yang Tidak Bisa Ditunda. Jakarta: PUSKAPA.

Sangaji, I. S. (2017). Analisi Dampak Pernikahan Dini Terhadap Kesehatan Reproduksi pada Remaja Putri Kecamatan Gamping Kabupaten 
Sleman. UNISA Yogyakarta. Retrieved from

http://digilib.unisayogya.ac.id/3779/1/

Islamiawati

Satalam

Sangaji.1610104445.Naskah

Publikasi.pdf
Sarwono, S. W. (2001). Psikologi Remaja. In Jakarta: Raja Grafindo Persada.

UNICEF. (2005). Early marriage: a harmful traditional practice, a statistical exploration. USA: The United Nations Children's Fund 